\title{
Bimbingan Kelompok Meningkatkan Keterampilan Berkomunikasi Siswa
}

\author{
Erwin Erlangga \\ Universitas Semarang, Jl. Soekarno Hatta, Tlogosari Kulon Semarang \\ e-mail: erwinerlangga@usm.ac.id
}

\begin{abstract}
This study aims to improve communication skills of the seventh-year students in MTs. Annur Karangjunti Kabupaten Brebes Jawa Tengah. Their low communication skills shown by unpolite interaction with the teacher, hurt others' feelings, and passive in the class. The sample were 35 students from 177 of population. This study used group guidance service and communication skills scale. The data analysis technique used t-test. According to the test results, there was an increase in the communication skills of the students, group 1 was 25,66\%, group 2 was 21,5\%, and group 3 was $28,54 \%$. In conclusion, group guidance service can influence communication skills of the seventh-year students in MTs. Annur Karangjunti Kabupaten Brebes Jawa Tengah.
\end{abstract}

Keywords: communication, group guidance, middle school

\begin{abstract}
Abstrak
Penelitian ini bertujuan untuk meningkatkan keterampilan berkomunikasi siswa Kelas VIII MTs. Annur Karangjunti Kabupaten Brebes Jawa Tengah, yang rendah yang ditandai dengan siswa sering berbicara tidak sopan kepada guru, selalu menyakiti hati orang lain ketika berbicara dan pasif dalam kegiatan belajar mengajar. Sampel penelitian berjumlah 35 siswa dari jumlah populasi 177 siswa. Penelitian ini menggunakan skala psikologis keterampilan berkomunikasi. Teknik analisis data dalam penelitian ini menggunakan rumus uji t. Berdasarkan hasil uji menggunakan uji $t$-test dengan taraf signifikan 5\% kelompok 1 menunjukkan $t_{\text {hitung }}=6,791>t_{\text {tabel }}=2,201$, kelompok $2 t_{\text {hitung= }} 6,981>t_{\text {tabel }}=2,201$, dan kelompok $3 t_{\text {hitung }}=9,645>t_{\text {tabel }}=2,228$. Dengan demikian bahwa terjadi peningkatan keterampilan berkomunikasi siswa, dimana peningkatan tersebut pada kelompok 1 sebesar 25,66\% pada kelompok 2 sebesar 21,5\% dan kelompok 3 sebesar 28,54\%. Dapat disimpulkan bahwa layanan bimbingan kelompok berpengaruh terhadap keterampilan berkomunikasi siswa kelas VIII MTs. Annur Karangjunti Kabupaten Brebes Jawa Tengah.
\end{abstract}

Kata Kunci: komunikasi, bimbingan kelompok, sekolah menengah

\section{Pendahuluan}

Manusia adalah makhluk sosial, sebagai makhluk sosial manusia senantiasa ingin berhubungan dengan manusia lainnya dan ingin mengetahui apa yang terjadi dengan dirinya. Rasa ingin tahu ini memaksa manusia untuk berkomunikasi dan menjadikan komunikasi sebagai kebutuhan dasar yang penting untuk hidup bermasyarakat. Komunikasi merupakan aktivitas manusia sehari-hari, sesama jenis ataupun lawan jenis. Dengan demikian komunikasi adalah aktivitas yang dilakukan oleh semua manusia dan membutuhkan sebuah keterampilan khusus agar dapat melahirkan kesuksesan.
Dalam hidup bermasyarakat orang yang tidak pernah berkomunikasi dengan orang lain niscaya akan terisolasi dari lingkungannya. Pengaruh keterisolasian ini dikhawatirkan dapat menimbulkan permasalahan yang kompleks, seperti tidak berkembangnya pengetahuan dan informasi baru yang bersumber dari masyarakat, serta apabila memiliki masalah sangat besar kemungkinan untuk mengalami kesulitan dalam proses penyelesaiannya.

Siswa sebagai bagian dari masyarakat dituntut dapat berkomunikasi dengan orang lain di lingkungan dimana siswa berinteraksi. Lingkungan yang dimaksud adalah sekolah, karena hampir sebagian waktu siswa banyak digunakan untuk berinteraksi 
di sekolah. Di lingkungan sekolah siswa akan senantiasa berkomunikasi dengan teman sebayanya, dengan guru-gurunya, dan dengan tenaga kependidikan yang senantiasa mereka temui di lingkungan sekolah. Tugas pokok siswa di sekolah adalah belajar, dengan belajar siswa akan memperoleh perubahan yang positif dan dapat berkembang secara optimal serta siap melaksanakan peranannya di masa yang akan datang.

Belajar bersosialisasi dan berkomunikasi dengan lingkungan sekitar merupakan proses perkembangan psikomotorik, afektif, dan kognitif dalam kehidupan individu. Siswa adalah anak yang menjalani proses pembelajaran. Berdasarkan hasil observasi peneliti dan informasi dari guru pembimbing, siswa di MTs. Annur Karangjunti Kabupaten Brebes Jawa Tengah menunjukkan adanya gejala-gejala (1) beberapa siswa dapat berkomunikasi dengan baik tetapi cukup banyak pula siswa yang mengalami keterampilan berkomunikasi yang rendah ditandai pada siswa-siswa tertentu, mereka berbicara dengan tidak sopan pada guru dan staf, menyela pembicaraan orang lain, jika berbicara menyinggung dan menyakiti hati orang lain baik disengaja maupun tidak disengaja; (2) banyak siswa dalam kegiatan belajar mengajar cenderung pasif, ketika berbicara di depan kelas anak mengalami rasa cemas, malu bertanya ketika materi tidak dikuasai, dan mengakibatkan hasil belajar yang rendah.

Pihak sekolah menyadari perlunya dilakukan upaya khusus untuk meningkatkan kemampuan berkomunikasi pada para siswanya. Upaya yang dilakukan untuk peningkatan keterampilan berkomunikasi dapat dilakukan dengan mengadakan kegiatan layanan bimbingan kelompok, mengingat bimbingan kelompok mempunyai berbagai macam kelebihan.

Pertama dengan bimbingan kelompok, anggota kelompok dapat berinteraksi dan saling mengeluarkan pendapat, memberikan tanggapan, saran, dan sebagainya.
Dengan interaksi dalam bimbingan kelompok, sikap-sikap negatif siswa seperti pemalu, suka memotong pembicaraan orang lain dan tidak menghargai akan terlihat sehingga pemimpin kelompok dapat memberikan informasi tentang sikap-sikap positif kepada siswa yang memiliki kekurangan tersebut.

Kedua dengan bimbingan kelompok siswa dapat saling memahami antar anggota kelompok sehingga timbul sikap percaya. Sikap percaya inilah yang membuat siswa dapat terbuka untuk mengutarakan isi hatinya. Ketiga dalam bimbingan kelompok siswa dilatih untuk mengkomunikasikan pikiran dan perasaan secara tepat dan jelas sehingga secara tidak langsung semua anggota kelompok dapat berlatih untuk berkomunikasi.

Keempat dalam bimbingan kelompok, anggota kelompok dilatih untuk mampu memecahkan konflik dan bentuk-bentuk masalah antar pribadi lain yang mungkin muncul dalam komunikasi dengan orang lain melalui cara-cara yang konstruktif. Selain itu kelima aspek keefektifan perilaku komunikasi antarpribadi menurut Kumar (dalam Wiryanto, 2004:36) yang meliputi keterbukaan, rasa positif, empati, dukungan dan kesetaraan tertampung dalam kegiatan layanan bimbingan kelompok, bukan pada layanan bimbingan konseling lainnya. Dalam bimbingan kelompok terdapat dinamika kelompok yang dapat memunculkan interaksi positif sehingga diharapkan secara optimal siswa dapat mengalami perubahan dan mencapai peningkatan yang positif setelah mengikuti kegiatan bimbingan kelompok.

Setiap melaksanakan layanan bimbingan kelompok terdapat beberapa faktor yang memengaruhi keefektifan layanan bimbingan kelompok. Faktor-faktor ini berupa faktor situasional dan faktor personal. Faktor situasional berarti bagaimana bimbingan kelompok tersebut dilakukan dan faktor personal menjelaskan sikap dan kemampuan anggota kelompok dapat memahami materi yang didiskusikan 
dalam layanan bimbingan kelompok. Hal ini yang menyebabkan setiap kegiatan layanan bimbingan kelompok memiliki tingkat keefektifan yang berbeda-beda. Depdikbud (1995: 1043) menyatakan bahwa keterampilan merupakan kecakapan, kepandaian, kemampuan untuk menyelesaikan tugas.

Effendy (2009: 9) mengemukakan bahwa istilah komunikasi atau dalam Bahasa Inggris comunication berasal dari kata Latin communicatio, dan dari kata communis yang berarti sama makna. Jadi apabila dua orang terlibat dalam komunikasi misalnya dalam bentuk percakapan, maka komunikasi akan terjadi atau berlangsung selama ada kesamaan makna mengenai apa yang dipercakapkan.

Moor (dalam Rohim, 2009: 8) menambahkan komunikasi adalah penyampaian pengertian antar individu. Ia menyatakan pula bahwa semua manusia dilandasi kapasitas untuk menyampaikan maksud, hasrat, perasaan, pengetahuan dan pengalaman dari orang yang satu kepada orang yang lain. Pada intinya komunikasi adalah pusat minat dan situasi perilaku di mana suatu sumber menyampaikan pesan kepada orang penerima dengan berupaya memengaruhi perilaku penerima tersebut.

Secara singkat, dapat disimpulkan bahwa keterampilan berkomunikasi adalah proses interaksi kegiatan manusia yang terdiri atas dua orang atau lebih yang saling memengaruhi dan bertukar informasi, pengetahuan, pikiran agar dapat menggugah partisipasi satu sama lain, sehingga informasi yang diberitahukan tersebut menjadi milik bersama.

Johnson (dalam Supratiknya, 1995: 10) menjelaskan bahwa agar mampu memulai, mengembangkan dan memelihara komunikasi yang akrab, hangat dan produktif dengan orang lain, siswa perlu memiliki sejumlah keterampilan dasar berkomunikasi atau ciri-ciri dalam berkomunikasi.

Pertama, harus saling memahami, agar dapat dipercaya. Sesudah saling percaya, harus saling membuka diri yakni saling mengungkapkan tanggapan-tanggapan terhadap situasi yang sedang dihadapi, termasuk kata-kata yang diucapkan atau perbuatan yang dilakukan oleh lawan komunikasi. Untuk dapat membuka diri sebelumnya harus menyadari perasaanperasaan maupun tanggapan-tanggapan batin. Membuka diri kepada orang lain dan mendengarkan dengan penuh perhatian ketika orang lain membuka diri adalah cara yang baik untuk memulai dan memelihara komunikasi.

Kedua, mampu mengkomunikasikan pikiran dan perasaan secara tepat dan jelas. Kemampuan ini juga harus disertai kemampuan yang menunjukkan sikap hangat dan rasa senang serta kemampuan mendengarkan dengan cara yang menunjukkan bahwa individu harus bisa memahami lawan komunikasi. Dengan saling mengungkapkan pikiran-perasaan dan saling mendengarkan, memulai, mengembangkan dan memelihara komunikasi.

Ketiga, mampu saling menerima dan saling memberikan dukungan atau saling menolong. Mampu menanggapi keluhan orang lain dengan cara-cara yang bersifat menolong yaitu dengan menunjukkan sikap memahami dan bersedia menolong sambil memberikan contoh seperlunya, agar mampu menemukan pemecahan-pemecahan dalam menghadapi masalah.

Keempat, mampu memecahkan konflik dan bentuk-bentuk masalah antar pribadi lain yang mungkin muncul dalam komunikasi dengan orang lain melalui cara-cara yang konstruktif artinya dengan cara-cara yang semakin mendekatkan dengan lawan komunikasi dan menjadikan komunikasi semakin tumbuh dan berkembang. Kemampuan ini sangat penting untuk mengembangkan dan menjaga kelangsungan komunikasi.

Keberhasilan maupun kegagalan dalam keterampilan berkomunikasi dipengaruhi oleh berbagai faktor, baik faktor dari luar maupun faktor dari dalam pelaku komunikasi itu sendiri yaitu komunikator dan komunikan yang meliputi antara lain citra 
diri, citra orang lain, merupakan faktor dari dalam sedangkan faktor dari luar yaitu lingkungan sosial dan kondisi fisik.

Menurut Widjaja (2000: 68) faktorfaktor yang dapat memengaruhi keterampilan berkomunikasi pada umumnya antara lain kebisingan, keadaan psikologis komunikan, kekurangan komunikator/ komunikan, kesalahan penilaian oleh komunikan, kurangnya pengetahuan komunikator/ komunikan, bahasa isi pesan berlebihan, bersifat satu arah, faktor teknis, kepentingan atau interest, prasangka dan cara penyajian yang verbalist.

Lunardi (2001: 34) mengungkapkan bahwa faktor-faktor yang memengaruhi komunikasi diantaranya adalah sebagai berikut: citra diri, bagaimana seseorang melihat dirinya sendiri dalam hubungan dengan orang lain dalam situasi tertentu; citra pihak lain, bagaimana seseorang melihat pihak yang diajaknya berkomunikasi; lingkungan fisik, tempat seseorang berada ketika berkomunikasi dengan pihak lain; lingkungan sosial, keberadaan seseorang sebagai penerima komunikasi maupun hanya hadir di sana; kondisi fisik, mental, emosi, kecerdasan; serta bahasa tubuh, gerakan tubuh yang berbicara tanpa kata-kata.

Kegiatan bimbingan kelompok akan terlihat hidup jika di dalamnya terdapat dinamika kelompok. Dinamika kelompok merupakan media efektif bagi anggota kelompok dalam mengembangkan aspekaspek positif ketika mengadakan komunikasi antarpribadi dengan orang lain.

Prayitno (1995: 178) mengemukakan bahwa bimbingan kelompok adalah suatu kegiatan yang dilakukan oleh sekelompok orang dengan memanfaatkan dinamika kelompok. Artinya, semua peserta dalam kegiatan kelompok saling berinteraksi, bebas mengeluarkan pendapat, menanggapi, memberi saran, dan lain sebagainya, apa yang dibicarakan itu semuanya bermanfaat untuk diri peserta yang bersangkutan sendiri dan untuk peserta lainnya.
Romlah (2001: 3) mendefinisikan bahwa bimbingan kelompok merupakan salah satu teknik bimbingan yang berusaha membantu individu agar dapat mencapai perkembangannya secara optimal sesuai dengan kemampuan, bakat, minat, serta nilai-nilai yang dianutnya dan dilaksanakan dalam situasi kelompok. Bimbingan kelompok ditujukan untuk mencegah timbulnya masalah pada siswa dan mengembangkan potensi siswa.

\section{Metode Penelitian}

Penelitian ini dilakukan di MTs. Annur Karangjunti Kabupaten Brebes Jawa Tengah. Penelitian dilakukan di sekolah tersebut melihat dari hasil observasi peneliti dan informasi dari guru pembimbing bahwa siswa-siswi MTs. Annur Karangjunti Kabupaten Brebes Jawa Tengah perlu diberikan bimbingan kelompok guna mengembangkan keterampilan berkomunikasi di lingkungan sekolah.

\section{Populasi, Sampel, dan Sampling}

Populasi. Sesuai dengan judul penelitian ini, maka yang menjadi populasi penelitian ini adalah siswa kelas VIII MTs. Annur Karangjunti Kabupaten Brebes Jawa Tengah yang berjumlah 5 kelas dengan jumlah keseluruhan 177 siswa.

Sampel. Populasi yang berjumlah 177 siswa dari 5 kelas dapat diambil sampel sebanyak 35 siswa atau $20 \%$ dari jumlah populasi (Arikunto, 2006: 134). Jumlah sampel tersebut telah memenuhi persyaratan yang ditentukan dalam pengambilan sampel terhadap populasi.

Sampling. Teknik pengambilan sampel yang digunakan dalam penelitian ini adalah purposive sampling. Digunakannya teknik purposive sampling karena peneliti sudah menetapkan terlebih dahulu jumlah sampel yang akan digunakan dalam penelitian, yaitu 35 siswa kelas VIII MTs. Annur Karangjunti Kabupaten Brebes Jawa Tengah yang mengalami masalah kurang terampil dalam berkomunikasi, dan dengan tujuan penelitian yaitu untuk meningkatkan 
keterampilan berkomunikasi siswa, serta mengetahui adanya pengaruh layanan bimbingan kelompok terhadap keterampilan berkomunikasi siswa.

Cara pengambilan sampel dengan purposive sampling, yaitu peneliti menetapkan sampel berdasarkan hasil analisis data yang terkait dengan jumlah siswa yang memiliki keterampilan komunikasi yang rendah. Pengambilan sampel berdasarkan tujuan yaitu meningkatkan keterampilan komunikasi yang rendah.

\section{Rancangan Penelitian}

Penelitian ini menggunakan rancangan pre-experiment (eksperimen tidak sebenarnya) atau kuasi eksperimen. Peneliti menggunakan one group pretest and posttest design karena tidak ada perbandingan dengan kelompok kontrol sehingga satu kelompok tes diberikan satu perlakuan yang sama sebelum dan sesudah mendapatkan perlakuaan tertentu.

Desain tersebut dapat digambarkan sebagai berikut:

\begin{tabular}{|lcc|}
$\begin{array}{l}\text { Pengukuran } \\
\text { (Pretest) }\end{array}$ & Perlakuan & $\begin{array}{r}\text { Pengukuran } \\
\text { (Posttest) }\end{array}$ \\
\hline T0 & $\mathrm{X}$ & $\mathrm{T} 1$ \\
\hline
\end{tabular}

Gambar 1. Skema one group pretest and posttest design

Adapun langkah-langkahnya sebagai berikut:

Menyebarkan skala psikologis keterampilan berkomunikasi kepada siswa (responden) sebelum diberi treatment sebagai pretest $\left(\mathrm{T}_{0}\right)$.

Melaksanakan layanan bimbingan kelompok pada responden yang diteliti. Layanan bimbingan kelom-pok diberikan sebanyak enam kali pertemuan. Adapun proses bimbingan kelompok terdiri dari tahap pembuka, tahap peralihan, tahap kegiatan, dan tahap penutup.

Menyebarkan skala psikologis keterampilan berkomunikasi yang disusun oleh peneliti dengan supervisi dari ahli argumentasi berda-sarkan dasar teoretik dari teori Harold Lasswell (Lasswell dan Kaplan, 1970) pada siswa setelah diberi treatment sebagai posttest $\left(\mathrm{T}_{1}\right)$.

Membandingkan $\mathrm{T}_{0}$ dan $\mathrm{T}_{1}$ untuk menentukan ada atau tidak ada perbedaan sebagai akibat dari perlakuan. Jika $\mathrm{T}_{0}$ (pretest) lebih kecil dari $\mathrm{T}_{1}$ (posttest) yang ditunjukkan oleh skor rata-rata secara signifikan maka layanan bimbingan kelompok efektif dalam meningkatkan keteram-pilan berkomunikasi.

Untuk mengetahui perbedaan secara signifikan antara hasil pretest dengan hasil posttest maka perlu dilakukan analisis data dengan menggunakan uji-t.

Instrumen yang digunakan adalah skala psikologis. Menurut Arikunto (2006), skala psikologis digunakan untuk mengungkap perasaan responden. Berdasarkan hasil uji validitas skala keterampilan berkomunikasi, dari 36 item pernyataan setelah dilakukan pengujian dengan SPSS yang tidak valid adalah nomor 3,5,6 sehingga item tersebut dihilangkan. Dengan demikian sebanyak 33 item dikatakan valid karena nilai lebih besar dari 0,60. Sedangkan pengujian reliabilitas menghasilkan nilai cronbach's alpha sebesar 0.656, sehingga item-item skala keterampilan berkomunikasi dikatakan baik.

\section{Hasil Penelitian dan Pembahasan}

Uji normalitas data menggunakan Kolmogorov-Smirnov dengan hasil $\mathrm{X} 1=$ 0,678 yang artinya nilai $>0,05$ maka populasi berdistribusi normal.

\section{Deskripsi Pretest Keterampilan Berkomunikasi Siswa}

Dari analisis deskripsi diperoleh ratarata untuk pretest keterampilan berkomunikasi siswa masing-masing kelompok. Kelompok 1 skor rata-rata 85,17; kelompok 2 skor rata-rata 85,33; kelompok 3 skor rata-rata 83,73. Skor terrendah keterampilan berkomunikasi siswa pada setiap kelompok adalah 79 dan skor ter- 
tingginya 89 , selanjutnya masing-masing skor pada setiap responden dimasukkan ke dalam interval pengkategorian.

Berdasarkan interval dapat disusun tabel distribusi frekuensi bergolong sebagai berikut:

Tabel 1

Kriteria Tingkat Keterampilan Berko-munikasi Siswa Pretest

\begin{tabular}{|c|c|c|c|c|c|}
\hline \multirow{2}{*}{ Kategori } & \multirow{2}{*}{ Interval } & \multicolumn{2}{|c|}{ Frekuensi } & \multirow[b]{2}{*}{ Kel.3 } & \multirow{2}{*}{ Persentase } \\
\hline & & Kel.1 & Kel.2 & & \\
\hline Tinggi & $115-140$ & 0 & 0 & 0 & $0 \%$ \\
\hline Sedang & 89-114 & 0 & 1 & 1 & $5,7 \%$ \\
\hline Rendah & $62-88$ & 12 & 11 & 10 & $94,3 \%$ \\
\hline $\begin{array}{l}\text { Sangat } \\
\text { Rendah }\end{array}$ & $35-61$ & 0 & 0 & 0 & $0 \%$ \\
\hline \multicolumn{2}{|c|}{ Jumlah } & 12 & 12 & 11 & $100 \%$ \\
\hline
\end{tabular}

Dilihat dari rata-rata keterampilan berkomunikasi siswa untuk masing-masing kelompok, kelompok 1 skor rata-rata 85,17; kelompok 2 skor rata-rata 85,33; kelompok 3 skor rata-rata 83,73. Maka dapat disimpulkan bahwa secara keseluruhan keterampilan berkomunikasi siswa MTs. Annur Karangjunti Kabupaten Brebes berada pada kategori rendah.

\section{Deskripsi Posttest Keterampilan Berkomunikasi Siswa}

Perlakuan yang diberikan adalah dengan memberikan 6 kali layanan bimbingan kelompok dengan tema komunikasi kepada siswa kelompok eksperimen yang setelah itu diberikan posttest di akhir perlakuan.

Dari analisis deskripsi diperoleh ratarata untuk posttest keterampilan berkomunikasi siswa masing-masing kelompok, kelompok 1 skor rata-rata 110,83; kelompok 2 skor rata-rata 106,83; kelompok 3 skor rata-rata 112,27 . Skor terrendah keterampilan berkomunikasi siswa pada setiap kelompok adalah 88 dan skor tertingginya 127 , selanjutnya masingmasing skor pada setiap responden dimasukan ke dalam interval pengkategorian.
Berdasarkan interval dapat disusun tabel distribusi frekuensi bergolong sebagai berikut:

Tabel 2

Kriteria Tingkat Keterampilan Berko-munikasi Siswa Posttest

\begin{tabular}{lccccc}
\hline \multirow{2}{*}{ Kategori } & \multirow{2}{*}{ Interval } & \multicolumn{2}{c}{ Frekuensi } & \multirow{2}{*}{ Persentase } \\
\cline { 3 - 6 } & & Kel.1 & Kel.2 & Ke.3 & \\
\hline Tinggi & $115-140$ & 4 & 3 & 5 & $34,3 \%$ \\
Sedang & $89-114$ & 7 & 9 & 6 & $62,9 \%$ \\
Rendah & $62-88$ & 1 & 0 & 0 & $2,8 \%$ \\
Sangat & $35-61$ & 0 & 0 & 0 & $0 \%$ \\
\begin{tabular}{c} 
Rendah \\
\multicolumn{2}{c}{ Jumlah }
\end{tabular} & 12 & 12 & 12 & $100 \%$ \\
\hline
\end{tabular}

Dilihat dari rata-rata keterampilan berkomunikasi siswa untuk masing-masing kelompok, kelompok 1 skor rata-rata 110,83; kelompok 2 skor rata-rata 106,83; kelompok 3 skor rata-rata 112,27. Maka dapat disimpulkan bahwa secara keseluruhan keterampilan berkomunikasi siswa MTs. Annur Karangjunti Kabupaten Brebes berada pada kategori sedang.

Dari hasil analisis data menunjukkan bahwa terjadi peningkatan keterampilan berkomunikasi antara sebelum dan sesudah dilakukan bimbingan kelompok yang terdiri dari tahap pembuka, peralihan, kegiatan, dan penutup. Hasil posttest menunjukkan adanya peningkatan skor rata-rata keterampilan berkomunikasi pada setiap kelompok. Berdasarkan hasil analisis data penelitian maka dikatakan bahwa perlakuan bimbingan kelompok yang dilakukan merupakan jenis layanan yang efektif untuk mengembangkan keterampilan berkomunikasi siswa. Hal ini karena subjek penelitian setelah mendapat bimbingan kelompok, berdasarkan data yang diperoleh menunjukkan adanya peningkatan keterampilan berkomunikasi dengan rata-rata peningkatan yang signifikan.

Setiap melaksanakan layanan bimbingan kelompok terdapat beberapa faktor yang memengaruhi keefektifan layanan bimbingan kelompok. Ini sesuai dengan penelitian Syahrul (2015). 
Layanan bimbingan kelompok adalah layanan primadona di sekolah artinya layanan semestinya dijadikan sarana untuk meningkatkan keterampilan siswa karena pada layanan ini terdapat dinamika kelompok. Salah satu keterampilan yang penting adalah keterampilan berargumentasi, melalui bimbingan kelompok terjadi dinamika kelompok yang dapat menambah wawasaan anggota kelompok untuk menjadi lebih bijaksana dalam berkomunikasi. Keterampilan berkomunikasi penting karena pada zaman modern komunikasi adalah sarana untuk menjalin persahabatan bahkan persatuan dan kesatuan bangsa. Ini sesuai dengan penelitian Purwanti (2010).

Peningkatan keterampilan berkomunikasi tersebut ditandai dengan siswa dapat saling memahami dan saling mengerti, siswa dapat menghargai pendapat orang lain, siswa berbicara dengan sopan pada guru, tidak menyela pembicaraan, jika berbicara tidak menyinggung dan menyakiti hati orang lain baik disengaja maupun tidak disengaja, siswa aktif dalam kegiatan belajar mengajar, ketika berbicara di depan kelas siswa lebih percaya diri, dan tidak malu bertanya tentang materi yang disampaikan.

\section{Simpulan dan Saran}

Berdasarkan hasil penelitian tentang pengaruh layanan bimbingan kelompok terhadap keterampilan berkomunikasi siswa, terdapat pengaruh yang signifikan dari layanan bimbingan kelompok terhadap keterampilan berkomunikasi, berdasarkan hasil kelompok 1 skor rata-rata secara keseluruhan 85,17. Setelah memperoleh layanan bimbingan kelompok, hasil posttest secara keseluruhan menunjukkan bahwa skor rata-rata keterampilan berkomunikasi siswa meningkat menjadi 110,83 termasuk dalam kategori sedang. Dengan demikian, siswa yang telah memperoleh layanan bimbingan kelompok, keterampilan berkomunikasi mereka meningkat, dimana peningkatan tersebut sebesar $25,66 \%$.
Kelompok 2 skor rata-rata secara keseluruhan 85,33. Setelah memperoleh layanan bimbingan kelompok, hasil posttest secara keseluruhan menunjukkan bahwa skor rata-rata keterampilan berkomunikasi siswa meningkat menjadi 106,83 termasuk dalam kategori sedang. Dengan demikian, siswa yang telah memperoleh layanan bimbingan kelompok, keterampilan berkomunikasi mereka meningkat, dimana peningkatan tersebut sebesar 21,5\%. Kelompok 3 skor rata-rata secara keseluruhan 83,73. Setelah memperoleh layanan bimbingan kelompok, hasil posttest secara keseluruhan menunjukkan bahwa skor ratarata keterampilan berkomunikasi siswa meningkat menjadi 112,27 termasuk dalam kategori sedang. Dengan demikian, siswa yang telah memperoleh layanan bimbingan kelompok, keterampilan berkomunikasi mereka meningkat, dimana peningkatan tersebut sebesar 28,54\%.

Berdasarkan hasil uji menggunakan uji t-test dengan taraf signifikansi 5\% kelompok 1 menunjukkan $t_{\text {hitung }}=6,791>$ $\mathrm{t}_{\text {tabel }}=2,201$, kelompok $2 \mathrm{t}_{\text {hitung }}=6,981>$ $t_{\text {tabel }}=2,201$, dan kelompok $3 t_{\text {hitung }}=9,645>$ $t_{\text {tabel }}=2,228$. Berdasarkan hasil perhitungan tersebut, berarti $\mathrm{H}_{1}$ diterima dan $\mathrm{H}_{0}$ ditolak sehingga dapat dikatakan bahwa "ada pengaruh yang signifikan bimbingan kelompok terhadap keterampilan berkomunikasi siswa".

Berdasarkan hasil penelitian yang menunjukkan bahwa bimbingan kelompok efektif meningkatkan keterampilan berkomunikasi siswa, maka seyogyanya guru bimbingan dan konseling melakukan kegiatan bimbingan kelompok secara terjadwal bagi siswa sehingga diharapkan siswa mampu memiliki keterampilan berkomunikasi yang baik. 


\section{Daftar Pustaka}

Arikunto, S. (2006). Prosedur Penelitian Suatu Pendekatan dan Praktik, Jakarta: Rineka Cipta.

Depdikbud. (1995). Kamus Besar Bahasa Indonesia, Jakarta: Balai Pustaka.

Effendi, O.U. (2009). Ilmu Komunikasi (Teori dan Praktek), Bandung: PT. Remaja Rosdakarya.

Lasswell, H.D. \& Kaplan, A. (1970). Power of Society, New Haven: Yale University Press.

Lunardi, A.G.. (2001). Komunikasi Mangena, Yogyakarta: Kanisius.

Prayitno. (1995). Layanan dan Bimbingan Konseling Kelompok, Jakarta: Ghalia Indonesia.

Purwanti, I.Y. (2010). Layanan Bimbingan Kelompok untuk Mengurangi Kesulitan Belajar, UNY.
Rohim, S. (2009). Teori Komunikasi (Perspektif, Ragam, dan Aplikasi), Jakarta: Rineka Cipta.

Romlah, T. (2001). Teori dan Praktek Bimbingan Kelompok, Malang: UNM.

Syahrul, M. (2015). Layanan Bimbingan Kelompok terhadap Peningkatan Penyesuaian Siswa, 1(1), 46-60.

Supratiknya. (1995). Komunikasi Antarpribadi Tinjauan Psikologis, Yogyakarta: Kanisius.

Widjaja. (2000). Ilmu Komunikasi (Pengantar Studi), Jakarta: Rineka Cipta.

Wiryanto. (2004). Pengantar Ilmu Komunikasi, Jakarta: Grasindo. 